\title{
Biomass accumulation and chemical composition of Massai grass intercropped with forage legumes on an integrated crop-livestock-forest system
}

\author{
Tatiana da Costa Moreno Gama ${ }^{1}$, Edimilson Volpe ${ }^{2}$, Beatriz Lempp ${ }^{1}$ \\ ${ }^{1}$ Programa de Pós-graduação em Agronomia, Universidade Federal da Grande Dourados, Dourados-MS, Brasil. \\ ${ }^{2}$ Centro de Pesquisa e Capacitação da AGRAER, Campo Grande-MS, Brasil.
}

\begin{abstract}
The objective was to evaluate the use of woody legumes (Albizia lebbeck, Cratylia argentea, Dipteryx Allata (Baru), a Leucaena hybrid (L. leucocephala + L. diversifolia), and Leucaena leucocephala cv. Cunningham) and herbaceous legumes (Arachis pintoi) intercropped with Panicum maximum cv. Massai, simultaneously implanted in a maize crop. The study made use of a randomized block experimental design with four replications. Assessments of biomass accumulation and forage nutritional value were made after the maize harvest, between June 2008 and October 2010. It was found that the residues of maize provided better growing conditions for Massai grass during the dry season. L. leucocephala cv. Cunningham and the Leucaena hybrid had the highest accumulation of all forage legumes evaluated, and provided the best nutritional value of all the arrangements tested. Of all woody legumes tested in this system, Leucaena was considered feasible for intercropping with Massai grass. The intercrop of perennial woody Baru with maize is not recommended. Albizia lebbeck and Cratylia argentea require further study, especially the yield assessment at different cutting intervals and cutting heights. Arachis pintoi had a low participation in the intercropping, showing greater performance over time, indicating slow thriving in this experimental condition.
\end{abstract}

Key Words: Albizia lebbeck, Arachis pintoi, crop-livestock integration, Cratylia argentea, Dipteryx allata, Leucaena leucocephala

\section{Introduction}

The Brazilian cattle industry is based on the exploitation of 170 million hectares of grassland. However, despite being the mainstay of national livestock, pasture areas have experienced a fast and sharp decline in their production capacity as a result of degradation processes, limiting or precluding the stock breeding activity.

Nitrogen is considered the most important mineral for plants because it increases the availability of forage and the amount of protein. The main way to supply nitrogen to forage plants is through chemical fertilizers. However, in intensive cattle-raising systems the direct expenses on fertilizers may represent more than half the production cost. The use of legumes intercropped with grasses can be an alternative tool for the system that can contribute to the supply of nitrogen by biological nitrogen fixation.

Received July 5, 2013 and accepted March 26, 2014.

Corresponding author: tmorenogama@gmail.com

http://dx.doi.org/10.1590/S1516-35982014000600001

Copyright $(2014$ Sociedade Brasileira de Zootecnia. This is an Open Access article distributed under the terms of the Creative Commons Attribution Non-Commercial License, which permits unrestricted non-commercial use, distribution, and reproduction in any medium, provided the original work is properly cited.
The intercropping of grasses and legumes may be an option to increase the production, the forage quality, and the profitability and sustainability of the system in tropical regions (Resende et al., 2003). However, according to Barcellos et al. (2008), the main limitation for the introduction of legumes in production systems is their low persistence under grazing.

A possible solution could be the use of some woody species. When compared with herbaceous species, they may have higher survival mechanisms in an intercropping situation. The height of woody legumes coupled with their deep roots makes these plants more capable of effectively isolating themselves from the worst effects of competition (Andersson et al., 2006).

There are several ways of introducing woody species in grass pastures. The most challenging form is the introduction of woody legumes in high density (to be used as shrubs for browsing). There are few species with the necessary characteristics for this purpose, especially in terms of productivity, acceptability, nutritional value, and adaptability to different soils and weather conditions.

Therefore, the objective of this study was to evaluate the intercropping of woody and herbaceous legumes with Panicum maximum cv. Massai, implanted in an integrated 
crop-livestock-forest system (maize crop), through the accumulation of forage and chemical composition.

\section{Material and Methods}

The experiment was conducted in an area with a rainy tropical savanna vegetation, with an average temperature of $23{ }^{\circ} \mathrm{C}$ (Köppen, 1948). The average annual precipitation is $1,527 \mathrm{~mm}, 28 \%$ of it occurring from April to September and $72 \%$ from October to March (Figure 1).

In October 2007, soil samples were collected from the upper $0-20 \mathrm{~cm}$ layer and chemically analyzed. The results were: $\mathrm{pH}$ (water) $=4.2$, available $\mathrm{P}=4.1 \mathrm{mg} \mathrm{dm}^{-3}$; available $\mathrm{K}=0.19, \mathrm{Ca}=1.4, \mathrm{Mg}=1.0, \mathrm{Al}=1.1, \mathrm{H}+\mathrm{Al}=$ $5.11, \mathrm{CEC}=7.71 \mathrm{cmol} / \mathrm{dm}^{-3}$, organic matter $=2.51 \%$, and base saturation $=33 \%$. In November 2007, a dolomitic lime $\left(2,700 \mathrm{~kg} \cdot \mathrm{ha}^{-1}\right.$ with $\left.100 \% \mathrm{TNP}\right)$ was used to increase the base saturation of the soil ( 0 -to- $20 \mathrm{~cm}$ layer) to $60 \%$. The soil tillage consisted of a $30-\mathrm{cm}$-deep chisel plowing, followed by a disk harrow plowing and two leveling harrowing.

Nine forage arrangements were evaluated: the intercropping of maize and Panicum maximum cv. Massai with woody legumes Albizia lebbeck (Albizia), Cratylia argentea (Cratilia), Dipteryx alatta (Baru), Leucaena leucocephala cv. Cunningham (Leucaena C.) and L. leucocephala + L. diversifolia (Leucaena hybrid) and herbaceous legume, Arachis pintoi cv. Belmonte (Arachis); the intercropping of Massai grass with maize; the intercropping of Massai grass with Arachis; and a Massai grass monocrop. Randomized block designs were used with four replications. The experimental area had $5,000 \mathrm{~m}^{2}$ and the plots were $9.8 \times 6.0 \mathrm{~m}$.

The woody legumes were sown in plots on December 5,2007 . One woody legume row was seeded for every three maize rows, so there was a $3.0 \mathrm{~m}$ spacing between them;

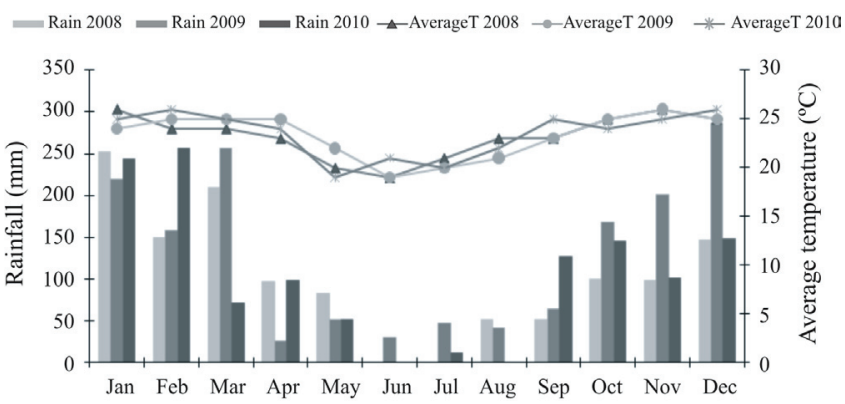

Source: Weather station from Centro de Pesquisa e Capacitação at Agraer (Cepaer).

Figure 1 - Monthly rainfall $(\mathrm{mm})$ and average temperature $\left({ }^{\circ} \mathrm{C}\right)$ during the experimental period (January 2008 to October 2010). maize and Massai grass occupied $75 \%$ of the area and the woody legumes occupied 25\%. Except for Baru, all legumes used were inoculated with rhizobia strains recommended and supplied by Embrapa Agrobiology (Bradyrhizobium elkanii for Albizia and Leucaena and Rhizobium tropici for Cratilia).

The maize monocrop (Zea mays cv. BRS 2020) was manually sowed on December 14, 2007, with a $0.75 \mathrm{~m}$ row spacing. The Massai grass monocrop was sowed on the same day. For the intercropping of maize with Massai grass, seeds were mixed and sown on the same day, using $3 \mathrm{~kg} \mathrm{ha}^{-1}$ of pure viable seeds per hectare of Massai grass. The average maize density was four plants per meter, reaching approximately 53 plants per ha ${ }^{-1}$. The Massai grass monocrop was sown with a $30 \mathrm{~cm}$ row-to-row spacing.

Arachis was planted in 1-m-spaced pits, on January 8, 2008. One (01) seedling was used per pit in rows. These seedlings, measuring approximately $30 \mathrm{~cm}$ in length, came from stolons whose roots were removed from the seedbed of Cepaer.

The maize crop fertilization used $400 \mathrm{~kg} \mathrm{ha}^{-1}$ with a NPK ratio of 05-30-15 and $10 \mathrm{~kg} \mathrm{ha}^{-1}$ zinc sulfate, copper and borax sulfate (Embrapa, 2000). Legumes were fertilized with $200 \mathrm{~kg} \mathrm{ha}^{-1}$ Yoorin magnesium thermophosphate (18\% $\left.\mathrm{P}_{2} \mathrm{O}_{5}, 18 \% \mathrm{Ca}, 7 \% \mathrm{Mg}\right), 10 \mathrm{~kg} \mathrm{ha}^{-1}$ zinc sulfate, copper and borax sulfate, and $0.5 \mathrm{~kg} \mathrm{ha}^{-1}$ sodium molybdate during row sowing. Maize sidedress fertilization used $100 \mathrm{~kg} \mathrm{~N} \mathrm{ha}^{-1}$ (urea-sourced) and $200 \mathrm{~kg} \mathrm{~K}_{2} \mathrm{O} \mathrm{ha}{ }^{-1}$ (potassium chloride $\mathrm{KCl}), 30$ days after emergence (DAE) on January 25, 2008. The Massai grass monocrop sidedress was fertilized on this same day, using $150 \mathrm{~kg} \mathrm{~N} \mathrm{ha}^{-1}$ (urea-sourced).

Maintenance fertilizations were performed annually, at the beginning of the rainy season, using a $40 \mathrm{~kg} \mathrm{ha}^{-1}$ 0-20-20 NPK ratio in all arrangements and $150 \mathrm{~kg} \mathrm{ha}^{-1} \mathrm{~N}$ (urea-sourced) in plots with no intercropping with legume species.

The assessments of forage biomass accumulation were made after the maize harvest (May 15, 2008), between June 2008 and July 2010, with three cuts every 60 days during the rainy season (November, January, and March) and one cut in the dry season of each experimental year (June 2008, July 2009, and 2010). The assessment results were equivalent to those accumulated during the growth period after the last harvest of maize intercropped with forage, on May 16, 2008. Massai grass was cut when the plant was 45-cm high, leaving a residue of approximately $10 \mathrm{~cm}$.

Two forage samples were collected from each plot, with a floor area of $3.0 \mathrm{~m}^{2}$ for grass and Arachis (3 squares of $1.0 \mathrm{~m}^{2}$ ), and $6.0 \mathrm{~m}^{2}$ for woody legumes. Weighing was performed immediately after the cuts to check the green weight. 
Forage samples were cut with a knapsack brushcutter for herbaceous materials, and with a sugar cane cutting machete for woody legumes. After the collection of each forage sample, the area was leveled by grazing animals; the animals were removed when the residual height of Massai grass was reached $(10 \mathrm{~cm})$.

The forage sample was wrapped in plastic bags and immediately taken to the laboratory for processing. The two forage samples obtained from each plot were homogenized and separated into two subsamples of $0.5 \mathrm{~kg}$ each. In one of the subsamples, the fresh material was weighed and then subjected to pre-drying in a forced air circulation chamber for 72 hours at $65{ }^{\circ} \mathrm{C}$; it was then weighed again in order to estimate the dry biomass accumulation. In the other subsample, the forage species were decomposed into different morphological components. In the case of samples of grass and herbaceous legume and in cv. Massai, the morphological components were separated into leaf blades (LF), sheath + stem (SS) and dead material (DM). Woodylegume components were separated into leaves + branches with diameters lower than $0.5 \mathrm{~cm}$ (edible material) and branches and stems with diameters greater than $0.5 \mathrm{~cm}$ (woody material). These subsamples were also processed to estimate the participation of each morphological component in the total biomass.

Through the forage samples it was possible to calculate the dry biomass and the dry green biomass accumulation of Massai grass, the accumulation of edible material (EM) of legumes, and the total green biomass accumulation (Massai grass and legumes), as well as the participation of legumes in the total accumulation of dry green biomass. The edible/ woody material ratio of woody legumes in rainy and dry seasons was also calculated.

The edible material of legumes was analyzed for in vitro dry matter digestibility (IVDMD) and crude protein (CP), according to methods described by Silva and Queiroz (2002). The leaf blade (LB) of the grasses components were subjected to near-infrared reflectance spectroscopy (NIRS) in accordance with procedures established by Marten et al. (1985). The reflectance data of the samples, in a wavelength range of 1100-2500 $\mathrm{mm}$, were obtained in a spectrometer (model NR5000: NIRS Systems, Inc., USA) coupled to a microcomputer. In vitro organic matter digestibility and CP values of Massai grass LB components were obtained by calibration equations for each variable, developed from analyses of approximately $20 \%$ of Massai grass by wet methods, as described by Euclides and Medeiros (2003).

Dependent variables were subjected to the analysis of variance, and means were compared by the Scott-Knott test at $5 \%$ probability using the SAEG software (Ribeiro Júnior,
2001). The residues associated with the arrangements and the evaluation seasons were estimated and the significant interactions were deployed to verify the effect of variation sources on the dry biomass and dry green biomass of Massai grass; the accumulation of the edible material of legumes; the total biomass accumulation; the participation of legumes in the total accumulation of dry biomass; and the woody edible/woody material ratio of legumes.

\section{Results and Discussion}

Significant interaction occurred among the sources of variation, treatments and evaluation periods for all tested variables. The evaluated forages presented a highly seasonal production from June 2008 to October 2010 (Table 1). In addition to variations in temperature and photoperiod, the seasonality of rainfall, characteristic of the tropics, does not allow for a uniform forage production during the year, according to Euclides et al. (2008). Therefore, the highest accumulation of forage occurred in the rainy season and the lowest in the dry season.

In the first evaluation period (dry season of 2008), the accumulation of forages intercropped with maize was higher than that obtained with Massai grass monocrop and Massai grass intercropped with Arachis.

The Massai grass monocrop showed low biomass accumulation compared with intercrops, showing its dependence on nitrogen to remain productive. However, the four months of accumulation (June-October 2008) of this evaluation period provided higher productivity than that reported by Brâncio et al. (2003), according to whom after three months of buildup during the dry season, Massai grass reached only $1,170 \mathrm{~kg} \mathrm{ha}^{-1}$ of dry green biomass (DGB).

These results corroborate those of Kluthcouski and Aidar (2003), who reported that responses in forage production are usually positive in crop-pasture integration because grasses are readily responsive to the higher nutrient supply present in the soil due to the use of the area in agriculture. Thus, the carrying capacity of the pasture and the productivity of the system are substantially increased compared with the rates observed in degraded pastures.

The Massai grass + Arachis intercropping showed the lowest accumulation of Massai grass DGB mainly in the first two evaluation periods. During the rainy season of 2009, the arrangements with Leucaena and Cratilia species hampered the growth of Massai grass in comparison with the other woody legumes; this may be due to the greater competition ability of these species. The Massai grass monocrop had the highest biomass accumulation compared with the other arrangements. The replacement of nitrogen 
Table 1 - Dry green biomass (DGB) of Panicum maximum cv. Massai and total arrangements (total DGB) in the rainy (sum of three cuts) and dry seasons

\begin{tabular}{|c|c|c|c|c|c|c|c|}
\hline Arrangements & Dry season/2008 & Rainy season/2009 & Dry season/2009 & Rainy season/2010 & Dry season/2010 & $\mathrm{CV} \%$ & Mean \\
\hline \multicolumn{8}{|c|}{ DGB Massai grass $\left(\mathrm{kg} \mathrm{ha}^{-1}\right)$} \\
\hline Massai monocrop & $1857 \mathrm{Bc}$ & $10488 \mathrm{Aa}$ & $2000 \mathrm{Ac}$ & $9002 \mathrm{Aa}$ & $2062 \mathrm{Ab}$ & 17.05 & 5082 \\
\hline Massai + Araquis & $922 \mathrm{Cd}$ & $5457 \mathrm{Da}$ & $1704 \mathrm{Ac}$ & $5785 \mathrm{Ba}$ & $1862 \mathrm{Ab}$ & 17.96 & 3146 \\
\hline Maize + Massai & $2796 A c$ & $7242 \mathrm{Ca}$ & $1205 \mathrm{Bd}$ & $5526 \mathrm{Bb}$ & $1634 \mathrm{Ac}$ & 15.71 & 3680 \\
\hline Maize + Massai + Araquis & $2652 \mathrm{Ab}$ & $7140 \mathrm{Ca}$ & $1010 \mathrm{Bc}$ & $5487 \mathrm{Bb}$ & $1294 \mathrm{Ab}$ & 17.60 & 3596 \\
\hline Maize + Massai + Baru & $2983 \mathrm{Ac}$ & $8195 \mathrm{Ba}$ & $1832 \mathrm{Ac}$ & $5956 \mathrm{Bb}$ & $1898 \mathrm{Ac}$ & 16.92 & 4173 \\
\hline Maize + Massai + Cratilia & $3102 \mathrm{Ab}$ & $6923 \mathrm{Ca}$ & $1410 \mathrm{Ac}$ & $6282 \mathrm{Ba}$ & $1645 \mathrm{Ab}$ & 17.24 & 4100 \\
\hline Maize + Massai + Albizia & $3025 \mathrm{Ac}$ & $8211 \mathrm{Ba}$ & $2137 \mathrm{Ac}$ & $6448 \mathrm{Bb}$ & $2047 \mathrm{Ac}$ & 17.08 & 4384 \\
\hline $\mathrm{CV} \%$ & 20.04 & 19.2 & 19.3 & 19.16 & 20.12 & & \\
\hline Mean & 2566 & 7381 & 1600 & 5897 & 1846 & & \\
\hline \multicolumn{8}{|c|}{ Total DGB $\left(\mathrm{kg} \mathrm{ha}^{-1}\right)^{*}$} \\
\hline Massai monocrop & $1857 \mathrm{Bc}$ & $10488 \mathrm{Aa}$ & 2000Ad & $9002 \mathrm{Ab}$ & $2062 \mathrm{Ac}$ & 15.12 & 5082 \\
\hline Maize + Massai + Cratilia & $3265 \mathrm{Ab}$ & $7708 \mathrm{Ba}$ & 1709Ac & $7823 \mathrm{Ba}$ & $1912 \mathrm{Bc}$ & 15.76 & 4484 \\
\hline Maize + Massai + Leucaena H. & $3171 \mathrm{Ac}$ & $7378 \mathrm{Bb}$ & $2226 \mathrm{Ad}$ & $8512 \mathrm{Aa}$ & $2628 \mathrm{Ac}$ & 15.45 & 4783 \\
\hline Maize + Massai + Leucaena C. & $3220 \mathrm{Ac}$ & $7830 \mathrm{Bb}$ & $2211 \mathrm{Ad}$ & $8332 \mathrm{Aa}$ & $2883 \mathrm{Ac}$ & 15.41 & 4895 \\
\hline Maize + Massai + Albizia & $3391 \mathrm{Ac}$ & $9052 \mathrm{Aa}$ & $2276 \mathrm{Ac}$ & $8076 \mathrm{Ab}$ & $2559 \mathrm{Ac}$ & 15.59 & 5071 \\
\hline $\mathrm{CV} \%$ & 18.01 & 16.15 & 16.0 & 16.60 & 15,06 & & \\
\hline Mean & 2695 & 7870 & 1827 & 7222 & 2098 & & \\
\hline
\end{tabular}

Values followed by the same letter in columns (uppercase) and rows (lower case) do not differ (P>0.05) by the Scott-Knott test.

* Accumulation of Massai grass + edible woody legumes (leaves + thin rods) or herbaceous legume (Arachis).

fertilization in this treatment during this evaluation period was shown to be effective and essential for maintaining grass productivity.

The intercropping with Albizia and Baru legumes did not affect the growth of Massai grass (because of shading and/or competition). Both intercrops presented a DGB accumulation of Massai grass only lower than that of the Massai grass monocrop, followed by the other arrangements. Andrade et al. (2004) evaluated the effect of artificial shading on DM accumulation rates in four kinds of grasses, including cv. Massai, which showed the best performance of all grasses, combining good shade tolerance and high production capacity.

In the dry season of 2009, the arrangements of maize with Massai grass and with Massai grass + Arachis, the only ones that did not have the effective participation of legumes (total DGB) or nitrogen replacement presented the lowest DGB accumulations compared with the other treatments. The nutrient reserves present in the soil due to the use of the area in agriculture were probably not sufficient to maintain the productivity of these arrangements in the dry season. Assessments of the rainy season of 2010 show that the Massai grass monocrop had the highest accumulations compared with other arrangements. The arrangements with Leucaena and Cratilia species in this season did not harm the growth of Massai grass, DGB accumulations being equal to other intercrops. In the dry season of 2010 there was no significant difference between the Massai grass monocrop and the intercrops with woody legumes.

Results also show that in the average arrangements, DGB accumulation in Massai grass monocrop was superior to others, followed by the intercrop with Albizia. This intercrop proved to be very efficient for the grass biomass accumulation, with fewer negative effects with respect to competition between species and/or shading.

The results obtained with Massai grass monocrop were expected, because forage grasses strongly respond to high doses of nitrogen. Brâncio et al. (2003) evaluated three Panicum maximum cultivars (Tanzania, Mombaça, and Massai) in a ten-year-old pasture in Cerrado soil with a nitrogen fertilization resembling that used in the present study, and they achieved an average dry matter yield of around 2,000-5,000 kg ha-1.

In the total DGB accumulation, it can be observed that woody legumes (except Baru) contributed to the absence of differences between the average intercrop arrangements and Massai grass monocrop, demonstrating the benefits for productivity in this type of intercropping.

In the Massai grass + Arachis arrangement, Arachis began to contribute with its production one year after its establishment, which was noticeable from the second evaluation time. From the 2009 dry season on, this 
intercropping eventually presented higher accumulation than that of the maize/Massai grass + Arachis intercropping, in which there is a $0.75 \mathrm{~m}$ spacing between rows, and legumes failed to thrive satisfactorily. This is probably due to excessive shading during the growth period with maize.

When assessing the dynamics and botanical composition of a Massai grass + Arachis pintoi pasture intercropping, Andrade et al. (2006) also observed that the participation of Arachis increased throughout the experimental period, particularly in pastures with a lower and more open canopy. The authors concluded that Arachis can be successfully intercropped with Massai grass if the pasture height in the pre-grazing condition is kept below $60 \mathrm{~cm}$ to prevent excessive shading of legumes.

One of the benefits of using woody legumes may be observed in the green edible biomass accumulation and in the participation (\%) of legumes in biomass accumulation (Table 2). It is noticeable that these arrangements with woody legumes in the course of the experiment contribute to increase the total DGB accumulation. However, the productivity of these woody legumes declined in dry seasons, presenting a higher proportion of stems.

An important feature of forages is their recovering capacity after cutting, and the results found in this study showed differences between the evaluated genotypes of legumes, especially Leucaena, which were more stable during the evaluation periods.

The effect of defoliation on the yield of woody legumes can be divided into three distinct phases. The first - a slow phase of biomass accumulation - is commonly observed after cutting (0-4 weeks), due to the small leaf area. This is followed by a period of maximum productivity (4-10 weeks), when leaf production increases sharply. Then comes the full- light-interception phase, when leaf senescence begins (10-24 weeks), with an increase in woody biomass and stability in leaf production. This period may be longer or shorter depending on the woody species being cut after its establishment or in dense crops (Gutteridge and Shelton, 1998).

The interval between cuts adopted in this study (eight weeks in the rainy season and 14 weeks in the dry season) was probably sufficient for the recovery of Leucaena, but not for Albizia and Cratilia, indicating the need to perform different cutting procedures for legumes.

Moreover, there is still no definite and more appropriate criterion for the height and interval between cuts for most woody legume species. Factors such as cutting height and cutting interval may have influenced this variation in the biomass accumulation and in the participation of Albizia and Cratilia. But the cutting interval usually has a more dominant effect on the yield than on the cutting height (Andersson et al., 2006).

Albizia and Cratilia did not maintain the biomass accumulation reached in the rainy season during the dry season, in contrast to what has been reported elsewhere. Ibrahim et al. (2001) reported that almost $40 \%$ of the annual dry matter yield (leaves + thin stems) of Cratilia occurred during the dry season, which was also observed in an experiment by Gama et al. (2009) in a protein bank situation. Xavier et al. (1990) and Gama et al. (2009) evidenced that in acidic soils with a high concentration of aluminum Cratilia showed a yield range of 13.1 to $14.3 \mathrm{tha}^{-1}$ per year of dry biomass. These results are higher than those observed in the present study.

Arachis did not show to thrive much, but the accumulation and participation of this legume increased over the experimental period, although its growth stopped

Table 2 - Edible biomass accumulation and participation of legumes in the total green biomass accumulation

\begin{tabular}{|c|c|c|c|c|c|c|c|}
\hline Arrangements & Dry season/2008 & Rainy season/2009 & Dry season/2009 & Rainy season/2010 & Dry season/2010 & $\mathrm{CV} \%$ & Mean \\
\hline \multicolumn{8}{|c|}{ Edible biomass $\left(\mathrm{kg} \mathrm{ha}^{-1}\right)$} \\
\hline Maize + Massai + Cratilia & $169 \mathrm{Ad}$ & $784 \mathrm{Bb}$ & $301 \mathrm{Bc}$ & $1562 \mathrm{Aa}$ & $318 \mathrm{Ac}$ & 23.48 & 631 \\
\hline Maize + Massai + Leucaena H. & 329Ac & 1189Aa & $619 \mathrm{Ab}$ & $1736 \mathrm{Aa}$ & $533 \mathrm{Ab}$ & 23.03 & 887 \\
\hline Maize + Massai + Leucaena C. & 308Ad & $1255 \mathrm{Ab}$ & $683 \mathrm{Ac}$ & $1932 \mathrm{Aa}$ & $636 \mathrm{Ac}$ & 22.78 & 956 \\
\hline Maize + Massai + Albizia & $365 \mathrm{Ac}$ & $842 \mathrm{Bb}$ & $140 \mathrm{Bd}$ & $1628 \mathrm{Aa}$ & 390Ac & 22.21 & 677 \\
\hline Massai + Araquis & $0.0 \mathrm{Bc}$ & $338 \mathrm{Cb}$ & $280 \mathrm{Bb}$ & $1494 \mathrm{Ba}$ & $0.0 \mathrm{Bc}$ & 23.40 & 422 \\
\hline $\mathrm{CV} \%$ & 26.82 & 24.4 & 25.31 & 24.55 & 24.14 & & \\
\hline Mean & 233 & 882 & 408 & 1.662 & 384 & & \\
\hline \multicolumn{8}{|c|}{ Participation of edible legumes $(\%)^{*}$} \\
\hline Maize + Massai + Cratilia & $05 \mathrm{Ac}$ & $11 \mathrm{Bb}$ & $16 \mathrm{Bb}$ & $21 \mathrm{Aa}$ & $14 \mathrm{Ab}$ & 28.91 & 13 \\
\hline Maize + Massai + Leucaena H. & $10 \mathrm{Ac}$ & $19 \mathrm{Ab}$ & $32 \mathrm{Aa}$ & $21 \mathrm{Ab}$ & $17 \mathrm{Ab}$ & 28.65 & 20 \\
\hline Maize + Massai + Leucaena C. & $10 \mathrm{Ac}$ & $20 \mathrm{Ab}$ & $34 \mathrm{Aa}$ & $26 \mathrm{Aa}$ & $20 \mathrm{Ab}$ & 28.06 & 22 \\
\hline Maize + Massai + Albizia & $11 \mathrm{Ab}$ & $10 \mathrm{Bb}$ & $06 \mathrm{Cc}$ & $22 \mathrm{Aa}$ & $14 \mathrm{Ab}$ & 28.09 & 13 \\
\hline Massai + Araquis & $0.0 \mathrm{Bd}$ & $06 \mathrm{Bc}$ & $13 \mathrm{Bb}$ & $21 \mathrm{Aa}$ & $0.0 \mathrm{Bd}$ & 28.60 & 08 \\
\hline $\mathrm{CV} \%$ & 30.11 & 29.02 & 29.15 & 28.04 & 28.89 & & \\
\hline Mean & 0.07 & 0.12 & 0.20 & 0.23 & 0.13 & & \\
\hline
\end{tabular}

Values followed by the same letter in columns (uppercase) and rows (lowercase) do not differ $(\mathrm{P}>0.05)$ by the Scott-Knott test.

* Woody legumes (leaf + thin stem). 
in the dry season. A. pintoi survives in well-drained areas, even though there is a severe leaf loss during the dry season, but resprouting is strong with the warmer temperatures of spring (Andrade et al., 2006). This work also found that weather conditions directly affected the production of this legume in the dry season of 2010.

The interaction between treatments and seasons had a significant effect on the participation of this legume in the total DGB accumulation (Table 2). In the average of treatments, intercrops with Leucaena were superior to other intercrops. However, the participation of legumes in the biomass accumulation was low, except for Leucaena in the dry season of 2009. Fisher et al. (1997) estimated that the participation of legumes in the pasture should be above $30 \%$ so that the legume litter provides greater nitrogen recovery for grasses.

Regarding the evaluation of edible material/(inedible) woody material ratios (EM/WM), Cratilia presented higher values than the other legumes (Table 3). Cratilia has shown many advantages such as high leaf retention, especially young leaves, and a good resprouting capacity during the dry season, one of its main characteristics (Andersson et al., 2006). However, the means of all treatments showed satisfactory results for this feature.

Gutteridge and Shelton (1998) say that it is possible to determine the best cut interval or grazing interval for woody legumes when comparing the change in weekly growth rate and the average growth rate. This period usually coincides when forages display a 50-60\% fraction of edible material from the total biomass of resprouts. This actually shows that the cut interval used in this study was too short for Cratilia, because it showed a $75 \%$ average of edible material in the evaluation times. However, the cut interval was adequate for the other evaluated species.

There was also a significant effect of the interaction between treatment and assessment time on the edible/ woody material ratio. In dry seasons, results were lower (lower amount of edible material) than those of rainy seasons. Therefore, as seen in the participation of legumes, the EM/WM ratio is also influenced by weather conditions.
Knowing the characteristics of a legume species is essential so as to enhance management techniques, ensuring the productivity and persistence of plants. Moreover, descriptions of growth and resprouting behaviors are important because they are related to the leaf/stem ratio and hence to the nutritional value of the plant.

In the total annual accumulation of dry green biomass it was also found that nitrogen fertilization plays an extremely important role in increasing the accumulation of dry biomass in the Massai grass monocrop (Table 4).

The intercropping with Albizia, in 2009, favored the production of Massai grass, and its participation in biomass accumulation, although small, made no difference in Massai grass monocrop, which received annual nitrogen replacements.

In 2010, when there was a greater stability of forage in intercrops, it was observed that treatments with Leucaena showed no significant differences in biomass accumulation compared with the Massai grass monocrop. Thus, both Leucaena intercrops, along with the Massai grass monocrop, are superior to other arrangements in terms of total accumulation of DGB. The largest crude protein accumulation per year $\left(1,500 \mathrm{~kg} \mathrm{ha}^{-1}\right)$ found in this study was higher than that observed by Euclides et al. (2008), whose evaluation of cv. Massai and Mombaça found values close to $1,100 \mathrm{~kg} \cdot \mathrm{ha}^{-1} \mathrm{CP}$, but lower than those reported by Volpe (2006), who assessed the $\mathrm{N}$ and $\mathrm{P}_{2} \mathrm{O}_{5}$ fertilizer levels and found 1,900 kg.ha ${ }^{-1} \mathrm{CP}$ in the highest doses applied during pasture maintenance.

There was an interaction between treatment and evaluation times for CP (Table 5). Intercrops with woody legumes Leucaena C. and Albizia benefited Massai grass: in the means of these arrangements, Massai grass had higher crude protein levels than the others.

Differences and/or similarities in nutritional value are always expected, since the crude protein content given to the plant is inherent, as well as a consequence of how each cultivar behaves under certain management procedures (fertilizing, cutting or grazing, and resting periods) (Brâncio et al., 2002). The results presented in this study

Table 3 - Edible material/woody material (EM/WM) ratio of woody legumes

\begin{tabular}{|c|c|c|c|c|c|c|c|}
\hline Legumes & Dry season/2008 & Rainy season/2009 & Dry season/2009 & Rainy season/2010 & Dry season/2010 & $\mathrm{CV} \%$ & Mean \\
\hline \multicolumn{8}{|c|}{ EM:WM* } \\
\hline Cratilia & $2.65 \mathrm{Ac}$ & $4.59 \mathrm{Aa}$ & $2.53 \mathrm{Ac}$ & $3.59 \mathrm{Ab}$ & $2.25 \mathrm{Ad}$ & 12.95 & 3.12 \\
\hline Leucaena H. & $1.07 \mathrm{Cc}$ & $2.57 \mathrm{Ca}$ & $1.81 \mathrm{Bb}$ & $2.33 \mathrm{Ca}$ & $1.50 \mathrm{Bb}$ & 12.20 & 1.86 \\
\hline Leucaena C. & $1.21 \mathrm{Cb}$ & $2.42 \mathrm{Ca}$ & $1.48 \mathrm{Bb}$ & $2.31 \mathrm{Ca}$ & $1.58 \mathrm{Bb}$ & 12.32 & 1.80 \\
\hline Albizia & $1.48 \mathrm{Bb}$ & $3.11 \mathrm{Ba}$ & $1.00 \mathrm{Cc}$ & $3.05 \mathrm{Ba}$ & $1.14 \mathrm{Cc}$ & 12.78 & 1.96 \\
\hline $\mathrm{CV} \%$ & 13.98 & 11.03 & 12.2 & 10.11 & 11,96 & & \\
\hline Mean & 1.60 & 3.17 & 1.48 & 2.81 & 1.62 & & \\
\hline
\end{tabular}

Values followed by the same letter in columns (uppercase) and rows (lowercase) do not differ $(\mathrm{P}>0.05)$ by the Scott-Knott test.

$* \mathrm{EM}=$ leaf + thin stem; $\mathrm{WM}=$ stem. 
Table 4 - Total accumulation of dry biomass in 2009 and 2010 and crude protein (CP) (kg ha $\left.{ }^{-1}\right)$ of Panicum maximum cv Massai and legumes*

\begin{tabular}{|c|c|c|c|c|c|c|c|c|}
\hline \multirow{2}{*}{ Arrangements } & \multicolumn{4}{|c|}{ Biomass year $2009\left(\right.$ t.ha ${ }^{-1}$ year $\left.^{-1}\right)$} & \multicolumn{4}{|c|}{ Biomass year $2010\left(\right.$ t.ha ${ }^{-1} \cdot$ year $\left.^{-1}\right)$} \\
\hline & Massai & Legumes & Total & $\mathrm{kg} \cdot \mathrm{ha}^{-1}$ of $\mathrm{CP}^{* *}$ & Massai & Legumes & Total & $\mathrm{kg} \cdot \mathrm{ha}^{-1}$ of $\mathrm{CP}^{* *}$ \\
\hline Massai monocrop & $13.7 \mathrm{~A}$ & - & $13.7 \mathrm{~A}$ & $1.096 \mathrm{~A}$ & $14.0 \mathrm{~A}$ & - & $14.0 \mathrm{~A}$ & $1.036 \mathrm{~B}$ \\
\hline Massai + Araquis & 7.9D & $0.65 \mathrm{C}$ & $8.7 \mathrm{~B}$ & $727 \mathrm{C}$ & $8.8 \mathrm{C}$ & $1.5 \mathrm{C}$ & $10.3 \mathrm{~B}$ & $845 B$ \\
\hline Maize + Massai & $9.4 \mathrm{C}$ & - & $9.4 \mathrm{~B}$ & $733 \mathrm{C}$ & $9.5 \mathrm{~B}$ & - & $9.5 \mathrm{C}$ & $618 \mathrm{C}$ \\
\hline Maize + Massai + Araquis & $9.2 \mathrm{C}$ & - & $9.2 \mathrm{~B}$ & $718 \mathrm{C}$ & $9.0 \mathrm{C}$ & - & $9.0 \mathrm{C}$ & $616 \mathrm{C}$ \\
\hline Maize + Massai + Baru & $10.9 \mathrm{~B}$ & - & $10.9 \mathrm{~B}$ & $851 \mathrm{~B}$ & $9.5 \mathrm{~B}$ & - & $9.5 \mathrm{C}$ & $660 \mathrm{C}$ \\
\hline Maize + Massai + Cratilia & $9.2 \mathrm{C}$ & $1.11 \mathrm{~B}$ & $10.3 \mathrm{~B}$ & $969 \mathrm{~A}$ & $9.7 \mathrm{~B}$ & $2.3 \mathrm{~B}$ & $12.0 \mathrm{~B}$ & $1.098 \mathrm{~B}$ \\
\hline Maize + Massai + Leucaena H. & $8.5 \mathrm{C}$ & $1.84 \mathrm{~A}$ & $10.3 \mathrm{~B}$ & $1.185 \mathrm{~A}$ & 11.1B & $2.8 \mathrm{~A}$ & $13.9 \mathrm{~A}$ & $1.446 \mathrm{~A}$ \\
\hline Maize + Massai + Leucaena C. & $8.9 \mathrm{C}$ & $1.93 \mathrm{~A}$ & $10.8 \mathrm{~B}$ & $1.307 \mathrm{~A}$ & $10.4 \mathrm{~B}$ & $3.2 \mathrm{~A}$ & $13.6 \mathrm{~A}$ & $1.510 \mathrm{~A}$ \\
\hline Maize + Massai + Albizia & $11.3 \mathrm{~B}$ & $1.00 \mathrm{~B}$ & $12.3 \mathrm{~A}$ & $1.175 \mathrm{~A}$ & $10.1 \mathrm{~B}$ & $2.5 \mathrm{~B}$ & $12.6 \mathrm{~B}$ & $1.210 \mathrm{~A}$ \\
\hline $\mathrm{CV} \%$ & 12.91 & 20.28 & 12.23 & 9.81 & 12.31 & 13.75 & 10.26 & 8.69 \\
\hline
\end{tabular}

Values followed by the same letter in columns (uppercase) and rows (lowercase) do not differ $(\mathrm{P}>0.05)$ by the Scott-Knott test.

* Woody legumes (leaf + thin stem).

** Results with weighted average of Massai grass leaves + edible material of legumes.

Table 5 - Means of crude protein contents (CP \%) in the edible material of Panicum maximum cv. Massai and legumes

\begin{tabular}{|c|c|c|c|c|c|c|}
\hline \multirow{2}{*}{ Arrangements } & \multicolumn{2}{|c|}{ CP Massai grass } & \multicolumn{2}{|c|}{ CP Legumes* } & \multirow{2}{*}{$\mathrm{CV} \%$} & \multirow{2}{*}{ Mean } \\
\hline & Rainy season & Dry season & Rainy season & Dry season & & \\
\hline Massai monocrop & $8.3 \mathrm{Ba}$ & $7.8 \mathrm{Bb}$ & - & - & 4.63 & 8.0 \\
\hline Massai + Araquis & $8.3 \mathrm{Ba}$ & 7.7Bb & $19.5 \mathrm{Ca}$ & $19.0 \mathrm{Ba}$ & 4.04 & 13.6 \\
\hline Maize + Massai & $7.8 \mathrm{Ca}$ & 7.6Ba & - & - & 4.97 & 7.7 \\
\hline Maize + Massai + Araquis & $7.9 \mathrm{Ca}$ & $7.7 \mathrm{Ba}$ & - & - & 4.85 & 7.8 \\
\hline Maize + Massai + Baru & $8.3 \mathrm{Ba}$ & $7.9 \mathrm{Bb}$ & - & - & 3.91 & 8.1 \\
\hline Maize + Massai + Cratilia & $8.3 \mathrm{Ba}$ & $7.8 \mathrm{Bb}$ & $20.6 \mathrm{Ca}$ & $19.5 \mathrm{Bb}$ & 4.06 & 14.1 \\
\hline Maize + Massai + Albizia & $8.4 \mathrm{Ba}$ & $8.3 \mathrm{Aa}$ & 21.9Ba & $21.8 \mathrm{Aa}$ & 4.18 & 15.1 \\
\hline $\mathrm{CV} \%$ & 6.88 & 6.1 & 5.02 & 5.11 & & \\
\hline Mean & 8.3 & 7.9 & 21.8 & 20.5 & & \\
\hline
\end{tabular}

Values followed by the same letter in columns (uppercase) and rows (lowercase) do not differ ( $\mathrm{P}>0.05)$ by the Scott-Knott test.

* Results with weighted average of leaves and thin stems for woody legumes (edible material).

show that this type of intercropping is a viable alternative for maintaining the nutritional value of the pasture.

With regard to the crude protein of leaf blades - the preferred part of the plant by grazing cattle - nitrogen fertilization of Massai grass monocrop and all other maize/ legume arrangements are adequate to the grass, since their contents are above $7 \%$. This value is considered critical by Minson (1990), below which voluntary restriction intake would occur by reducing the activity of microorganisms in the rumen and thus the cellulose digestion rate, increasing the forage retention time within the rumen. However, this author suggests that the $12 \%$ content of crude protein in forages is the most suitable for the beef cattle production system.

Some studies on the nutritional value of Massai grass have indicated that its protein content is usually lower than those reported for other Panicum cultivars (Brâncio et al., 2002). In comparative experiments on the chemical composition of Panicum maximum cultivars (Massai, Mombaça, and Tanzania), Euclides et al. (2008) and Cavali et al. (2005) found that the CP content of the Massai grass was lower than that of other cultivars.
In general, the Massai grass $\mathrm{CP}$ contents were higher during the rainy season. However, the results for Massai grass were lower than those described by Euclides et al. (2008), who found a $9.8 \% \mathrm{CP}$, but close to the $7.8 \%$ presented by Brâncio et al. (2003).

As to the CP contents of the legumes, the Leucaena species and Albizia were superior to Cratilia and Arachis. However, it was observed that the $\mathrm{CP}$ of all legumes had high values (>19\%) both in rainy and dry seasons, and all the species studied, except Baru, were consumed by the animals during the grazing period to level the experimental area after the evaluation of the cut. Therefore, management practices that maintain higher proportion of legumes in the pasture can determine the improvement in the nutritional quality and increase the CP content as recommended by Minson (1990).

Studies on forage production and animal performance for a higher nutritional quality of 13 woody forage legumes, including the same in this study, showed that $A$. lebbeck had one of the highest crude protein levels (23.6\%), higher than that found in this work for the same species. Other woody forage legumes had similar values to this study, 
except for $C$. argentea, with a CP level around 11.8\% (Barnes, 1999). The crude protein content of Arachis was similar to that reported by Paris et al. (2009), about $20 \%$. According to Valentim et al. (2003), the CP content of Arachis usually ranges from 18 to $24 \%$.

The in vitro digestibility was greater in the arrangements with Massai grass monocrop and intercropped with woody legumes Leucaena C. and Albizia (Table 6). All arrangements presented lower results for digestibility than those reported in the literature for other Panicum cultivars (Brâncio et al., 2002; Cavali et al., 2005; Euclides et al., 2008).

According to Lempp et al. (2000), who evaluated the anatomical structure and the in vitro incubation residue of Tanzania, Mombaça, and Massai cultivars, Massai grass presents lower digestibility, the highest frequency of girder I structure of this cultivar being one of the possible causes of the restriction to a better digestion. This digestion restriction can be attributed to the lower accessibility of microorganisms to the cellular content (Lempp et al., 2004). However, Brâncio et al. (2003) observed no differences in DM intake by cattle on Massai grass and Mombaça grass pastures, both in the rainy and dry seasons.

Nitrogen fertilization had a positive response on the IVOMD for Massai grass monocrop. In a study by Volpe et al. (2008), the estimated values of IVOMD in Massai grass leaves showed a maximum value of $66 \%$ in the calculated maximum base saturation and highest $\mathrm{N}$ rates; for lower levels of fertilization and liming the estimated value was
$62 \%$. These IVOMD values are above the average for tropical forage grasses. Moreover, the results are concordant with Lempp et al. (2004), for whom nitrogen can improve the nutritional value of Massai grass.

Analyzing the effect of the forage sampling time on the characteristics that make up the nutritional value, it was found that the best results generally occurred in rainy seasons because there was a trend of higher digestibility. During that time, carbohydrates were used along with the available nitrogen for the synthesis of amino acids and proteins, thus increasing the crude protein content (Table 5).

Albizia and Arachis showed highest digestibility, followed by the Leucaena species. In Mexico, SolorioSanchez et al. (2000) observed high levels of IVDMD $(70 \%)$ in eight-month-old plants (A. lebbeck), a similar result to that observed in this study. Despite showing lower digestibility values than other legumes, Cratilia had higher results than those reported in literature, since Andersson et al. (2006) and Gama et al. (2009) found IVDMD values of $48 \%$ and $46 \%$, respectively.

Valentim et al. (2003) observed similar results for Arachis, which showed an IVDMD value of $68 \%$. Leucaena is also known for its high nutritional value and acceptability and for its similar chemical composition to that of Alfalfa. The results found in this study are similar to those reported by several authors (Barcellos et al., 2008; Jetana et al., 2011). Differences between the Leucaena hybrid and Leucaena l. cv Cunningham were also reported by Barcellos (2006).

Table 6 - Means of in vitro organic matter digestibility (IVOMD) and in vitro digestible dry matter (IVDMD) of Panicum maximum cv Massai and legumes

\begin{tabular}{|c|c|c|c|c|}
\hline \multirow{2}{*}{ Arrangements } & \multicolumn{2}{|c|}{ IVOMD Massai grass (\%) } & \multirow{2}{*}{$\mathrm{CV} \%$} & \multirow{2}{*}{ Means } \\
\hline & Rainy season & Dry season & & \\
\hline Massai monocrop & $56.4 \mathrm{Aa}$ & $56.5 \mathrm{Aa}$ & 4.77 & 56.4 \\
\hline Massai + Araquis & $53.7 \mathrm{Ba}$ & $52.3 \mathrm{Cb}$ & 4.96 & 53.0 \\
\hline Maize + Massai & $54.2 \mathrm{Ba}$ & $53.2 \mathrm{Bb}$ & 4.03 & 53.5 \\
\hline Maize + Massai + Araquis & $55.7 \mathrm{Ba}$ & $52.2 \mathrm{Cb}$ & 3.99 & 53.4 \\
\hline Maize + Massai + Baru & $52.2 \mathrm{Cb}$ & $53.8 \mathrm{Ba}$ & 4.54 & 53.0 \\
\hline Maize + Massai + Cratilia & $55.0 \mathrm{Ba}$ & $52.8 \mathrm{Cb}$ & 4.35 & 54.9 \\
\hline Maize + Massai + Leucaena H. & $52.4 \mathrm{Ca}$ & $52.0 \mathrm{Ca}$ & 4.01 & 52.2 \\
\hline Maize + Massai + Leucaena C. & $55.8 \mathrm{Aa}$ & $56.8 \mathrm{Aa}$ & 4.16 & 56.5 \\
\hline Maize + Massai + Albizia & $54.5 \mathrm{Ba}$ & $55.7 \mathrm{Aa}$ & 4.31 & 55.0 \\
\hline $\mathrm{CV} \%$ & 7.25 & 6.33 & & \\
\hline \multirow[t]{2}{*}{ Mean } & 52.8 & 52.3 & & \\
\hline & \multicolumn{2}{|c|}{ IVDMD legumes (\%) } & & \\
\hline Massai + Araquis & $70.0 \mathrm{Aa}$ & $61.1 \mathrm{Bb}$ & 3.12 & 65.3 \\
\hline Maize + Massai + Cratilia & $57.0 \mathrm{Da}$ & $55.7 \mathrm{Db}$ & 3.28 & 56.2 \\
\hline Maize + Massai + Leucaena H. & $58.5 \mathrm{Cb}$ & $59.8 \mathrm{Ca}$ & 3.05 & 59.2 \\
\hline Maize + Massai + Leucaena C. & $58.6 \mathrm{Cb}$ & $60.3 \mathrm{Ca}$ & 3.19 & 59.8 \\
\hline Maize + Massai + Albizia & $68.2 \mathrm{Ba}$ & $64.2 \mathrm{Ab}$ & 2.88 & 66,6 \\
\hline CV\% & 6.41 & 5.5 & & \\
\hline Mean & 62.5 & 60.3 & & \\
\hline
\end{tabular}

Values followed by the same letter in columns (uppercase) and rows (lower case) do not differ ( $>0.05)$ by the Scott-Knott test. 


\section{Conclusions}

The integration system adopted enhances the growth conditions of Massai grass during the dry season. Of all intercrops evaluated, Massai grass with Leucaena species is considered the most viable arrangement, since it has a similar performance to that of Massai grass monocrop receiving high nitrogen fertilization. The intercropping of Maize and Massai Grass is not recommended for the woody legume Baru. Albizia and Cratilia require further study, especially with regard to the yield assessment at different cutting intervals and cutting heights. Arachis pintoi had a low participation in the intercropping, showing greater performance over time, indicating slow thriving in experimental conditions.

\section{Acknowledgments}

This study was financed by Fundação de Apoio ao Desenvolvimento do Ensino, Ciência e Tecnologia do Estado de Mato Grosso do Sul (FUNDECT - MS).

\section{References}

Andersson, M. S.; Peter, M. Schultze-Kraft, R.; Franco, L. H. and Lascano, C. E. 2006. Phenological agronomic and forage quality diversity among germplasm accessions of tropical legume shrub Cratylia argentea. Journal of Agricultural Science 144:237-248.

Andrade, C. M. S.; Garcia, R.; Valentim, J. F. and Pereira, O. G. 2006. Grazing management strategies for massaigrass-forage peanut pastures. 2. Productivity, utilization and sward structure. Revista Brasileira de Zootecnia 35:343-351.

Andrade, C. M. S.; Valentim, J. F.; Carneiro, J. C. and Vaz, F. A. 2004. Crescimento de gramíneas e leguminosas forrageiras tropicais sob sombreamento. Pesquisa Agropecuária Brasileira 39:263-270.

Barcellos, A. O. 2006. Avaliação agronômica de híbrido interespecífico de Leucaena e sua qualidade em associação com Brachiaria brizantha cv. Marandu. Tese(D.Sc.). Faculdade de Ciências Agrárias e Veterinárias/Universidade Estadual Paulista, Jaboticabal.

Barcellos, A. O.; Ramos, A. K. B.; Vilela, L. and Martha Junior, G. B. 2008. Sustentabilidade da produção animal baseada em pastagens consorciadas e no emprego de leguminosas exclusivas, na forma de banco de proteína, nos trópicos brasileiros. Revista Brasileira de Zootecnia 37:51-67.

Barnes, P. 1999. Fodder production of some shrubs and trees under two harvest intervals in subhumid souther Ghana. Agroforestry Systems 42:139-147.

Brâncio, P. A.; Euclides, V. P. B.; Nascimento Júnior, D.; Fonseca, D. M.; Almeida, R. G.; Macedo, M. C. M. and Barbosa, R. A. 2003. Avaliação de três cultivares de Panicum maximum Jacq. sob pastejo: Disponibilidade de forragem, altura do resíduo póspastejo e participação de folhas, colmos e material morto. Revista Brasileira Zootecnia 32:55-63.

Brâncio, P. A.; Nascimento Júnior, D.; Euclides, V. P. B.; Regazzi, A. J.; Almeida, R. G.; Fonseca, D. M. and Barbosa, R. A. 2002. Avaliação de três cultivares de Panicum maximum Jacq. sob pastejo: composição química e disponibilidade da forragem. Revista Brasileira de Zootecnia 31:1605-1613.
Cavali, J.; Sales, M. F. L.; Valentim, J. F.; Andreade, C. M. S. and Porto, M. O. 2005. Composição química de cultivares de Panicum maximum em Rio Branco, Acre. In: Anais da 42a Reunião Anual da Sociedade Brasileira de Zootecnia. Sociedade Brasileira de Zootecnia, Goiânia.

EMBRAPA - Empresa Brasileira de Pesquisa Agropecuária. Centro Nacional de Pesquisa de Milho e Sorgo. 2000. Cultivo do milho. Embrapa CNPMS, Sete Lagoas. (EMBRAPA-CNPMS. Sistemas de Produção, 1). Available at: <http:www.cnpms.embrapa/br>. Accessed on: Sep. 25, 2007.

Euclides, V. P. B.; Macedo; M. C. M.; Zimmer, A. H. L. J. and Oliveira, M. P. 2008. Avaliação dos capins mombaça e massai sob pastejo. Revista Brasileira de Zootecnia 37:18-26.

Euclides, V. P. B. and Medeiros, S. R. 2003. Valor nutritivo das principais gramíneas cultivadas no Brasil. Embrapa Gado de Corte, Campo Grande. (Embrapa Gado de Corte. Documentos, 139).

Fisher, M. J.; Rao, I. M. and Thomas, R. J. 1997. Nutrient cycling in tropical pastures, with special reference the neotropical savannas. p.371-382. In: Proceedings of the 18th International Grassland Congress. Association Management Centre, Winnipeg/Saskatoo.

Gama, T. C. M.; Zago, V. C. P.; Nicodemo, M. L. F.; Laura, V. A.; Volpe, E. and Morais, M. G. 2009. Composição bromatológica, digestibilidade in vitro e produção de biomassa de leguminosas forrageiras lenhosas cultivadas em solo arenoso. Revista Brasileira de Saúde e Produção Animal 10:560-572.

Gutteridge, R. C. and Shelton, H. M. 1998. Forage tree legumes in the tropical agriculture. The Tropical Grassland Society of Australia Inc., Saint Lucia, Australia.

Ibrahim, M.; Franco, M.; Pezo, A.; Camero, A. and Araya. J. L. 2001. Promoting intake of Cratylia argentea as a dry season supplement for cattle grazing Hyparrhenia rufa in the subhumid tropics. Agroforestry Systems 51:167-175.

Jetana, T.; Vongpipatana, C.; Usawang, S. and Thongruay, S. 2011 The use of tropical protein-rich leaves as supplements to Thai swamp buffalo receiving a basal diet of rice straw and treated leucaena (Leucaena leucocephala). Tropical Animal Health Production 43:57-67.

Kluthcouski, J. and Aidar, H. 2003. Sistema Santa Fé. p.405-441. In: Integração lavoura-pecuária. Kluthcouski, J.; Stone, L. F. and Aidar, H., eds. Embrapa Arroz e Feijão, Santo Antônio de Goiás.

Köeppen, W. 1948. Climatologia: con um estúdio de los climas de la Tierra. Fondo de Cultura Economica, México.

Lempp, B.; Euclides, V. P. B.; Morais, M. G. and Victor, D. M. 2000. Avaliação do resíduo da digestão de três cultivares de Panicum maximum. In: Anais da 37a Reunião Anual da Sociedade Brasileira de Zootecnia. Sociedade Brasileira de Zootecnia, Viçosa, MG.

Lempp, B.; Kichel, A. G.; Gomes, R. and Silva, E. B. A. 2004. Proporção e arranjo de tecidos em lâminas foliares de Panicum maximum cv Massai. In: Anais da 41 a Reunião Anual da Sociedade Brasileira de Zootecnia. Sociedade Brasileira de Zootecnia, Campo Grande.

Marten, G. C.; Shenk, J. S. and Barton II, F. E. 1985. Near infrared reflectance spectroscopy (NIRS), analysis quality. Agriculture Handbook, 643. USDA, Washington.

Minson, D. J. 1990. Forage in ruminant nutrition. Academic Press, San Diego.

Paris, W.; Cecato, U.; Martins, E. N.; Limão, V. A.; Galbeiro, S. and Oliveira, E. 2009. Estrutura e valor nutritivo da pastagem de Coastcross -1 consorciada com Arachis pintoi, com e sem adubação nitrogenada. Revista Brasileira de Saúde Produção Animal 10:513-524.

Resende, A. S.; Xavier, R. P.; Quesada, D. M.; Urquiaga, S.; Alves, B. J. R. and Boddey, R. M. 2003. Use of green manures in increase inputs of biological nitrogen fixation to sugar cane. Biology and Fertility of Soils 37:215-220.

Ribeiro Júnior, J. I. 2001. Análises estatísticas no SAEG. UFV, Viçosa, MG. 
Silva, D. J. and Queiroz, A. C. 2002. Análises de alimentos (métodos químicos e biológicos). 3.ed. UFV, Imprensa Universitária, Viçosa, MG.

Solorio-Sanchez, F. J.; Armendariz-Yanez, I. and Ku-Vera, J. 2000. Chemical composition and in vitro dry matter digestibilit of some fodder trees from South-east México. Livestock Research for Rural Development 16:4-7.

Valentim, J. F.; Andrade, C. M. S.; Mendonça, H. A. and Sales, M. F. L. 2003. Velocidade de estabelecimento de acesso de amendoim forrageiro na Amazônia Ocidental. Revista Brasileira de Zootecnia $32: 1-12$.
Volpe, E. 2006. Saturação por bases, fósforo e nitrogênio no estabelecimento e manutenção de capim-massai. Tese (D.Sc.). Universidade Federal de Mato Grosso do Sul, Dourados.

Volpe, E.; Marchetti, M. E.; Macedo, M. C. M. and Lempp, B. 2008. Acúmulo de forragem e características do solo e da planta no estabelecimento de capim-massai com diferentes níveis de saturação por bases, fósforo e nitrogênio. Revista Brasileira de Zootecnia 37:228-237.

Xavier, D. F.; Carvalho, M. M. and Botrel, M. A. 1990. Curva de crescimento e acumulação de proteína bruta de leguminosa Cratylia floribunda. Pasturas Tropicais 12:35-38. 